\title{
THE ENFORCEMENT OF COLLECTIVE LABOR AGREEMENTS BY ARBITRATION*
}

\author{
Charles O. Gregori $\dagger$
}

$\mathrm{I}^{\mathrm{N}}$

N SPITE of the developments in labor relations and collective bargaining over the last ten years, it is safe to say that there is still no settled American law governing the status of collective labor agreements and their enforceability. This case of arrested development may not have been particularly serious before I935, when the NLRA became law. But now that the government has committed industry to a far-reaching program of virtual compulsory collective bargaining, we must establish some feasible techniques for the interpretation, application, and enforcement of collective agreements.

One explanation of the absence of such a development may be that the enforcement of contracts has traditionally been a concern of the states, and they have unfortunately followed no trend toward a uniform theory adapted to the adequate settlement of claims arising from collective agreements. Nor are they in a position to do so effectively. On the other hand, Congress has created the conditions that have resulted in thousands of new collective agreements, and it is in a position to provide some uniform method for their application and enforcement. It is true that under our federal-state system of government, Congress is traditionally supposed to keep its hands off of matters pertaining to the interpretation and enforcement of contracts. But we are faced with a practical and unprecedented situation of Congress' own making. And it may have to provide the solution by exercising the same powers with which it created the NLRA in the first place-the cause of these numerous collective agreements.

The use by Congress of its commerce power seems most appropriate in this situation. Many present-day collective agreements have very decided interstate implications, some of them covering the various units of industrial empires which spread from coast to coast. It is certainly as tenable to suppose that Congress has the constitutional power under the commerce clause to provide a uniform method for the administration of these collec-

* [A chapter from Labor and the Law, to be published in the late summer of 1946 by W. W. Norton \& Company, New York. Although this volume is intended for lay readers, it is believed that the author's observations on arbitration merit the attention of the legal profession.-Ed.]

$\dagger$ Professor of Law, University of Chicago Law School. 
tive agreements as it was to assume that it could originally impose on industry under the NLRA the conditions which led to universal organization and collective bargaining. If it were necessary to guarantee independent organization and collective bargaining for the purpose of protecting commerce from the disruptive effects of strikes concerning organization and recognition of unions, then it is equally necessary to protect commerce from the ravages of disputes concerning the application and enforcement of the resulting agreements.

Congress and the state legislatures have so far refrained from spelling out any procedures for the enforcement of collective agreements. They have left that job to the courts, and the judges have the most rudimentary notions about what is required. But even if the courts had clearer conceptions of an adequate procedure, there are good reasons why they could do little about it without the aid of legislatures. One reason is that labor unions have no separate legal status such as corporations enjoy. Since they are not persons in the eyes of the law, they have no standing before the courts as parties in suits to enforce contracts or as parties being sued under their terms. In many states, unions may enjoy the benefits of legal personality through incorporation, as long as they are willing to assume the responsibilities which such a step entails. $A$ few unions have already found it convenient to incorporate. But most of them seem reluctant to abandon some of the advantages of loose and informal association and look with suspicion at the consequences of incorporation, such as disclosure of their internal affairs. This situation can be corrected only by legislation creating a status for unincorporated unions as legal persons, to sue and be sued without the formality of incorporation. In the absence of such legislation our courts may simply decide to treat unions as legal persons for certain purposes, as indeed a few have already done. But this involves a process of judicial legislation which few courts relish and which affords no promise of a uniform development fitted to the needs of the occasion.

Another reason for the rudimentary development in our common law regarding the enforceability of collective agreements is the tendency of lawyers and judges to think about these agreements in terms of conventional contract law. In a sense they are contracts. But, strictly speaking, they are not contracts at all in light of what that term traditionally signifies. As one court has said, the collective agreement "resembles in many ways a treaty." This characterization is exceedingly apt. For the rigors of collective bargaining with strikes, boycotts, and picketing frequently

× Yazoo \& M.V.R. Co. v. Webb, 64 F. 2d go2, 903 (C.C.A. 5th, r933). 
suggest warring factions, each anxious to make peace with the other on a basis of selfish personal advantage. Indeed, the highest court in England has supported this analogy by declaring that collective agreements are not enforceable in a court but only by the immediate parties, ${ }^{\mathrm{Ia}}$ fairly implying that unions can hope to secure compliance with their terms only by striking. This counsel of despair sacrifices most of the stabilizing advantages inherent in written collective agreements. For if these undertakings fail to keep the parties on a fairly businesslike basis of mutual give and take, much of their contribution to civilized progress is lost. Fortunately, our courts do not share the hopeless attitude of the House of Lords, although their attempts to provide redress under these agreements are still far from satisfactory.

Judicial developments in this country concerning the enforcement of collective agreements fall roughly into three categories-none of them according to an unincorporated union, as such, actual participation in litigation. Under one category, collective agreements between a union and an employer result in a custom or usage which is to be reflected in the individual "contracts" of employment made by each worker with the employer. ${ }^{2}$ This theory implies the nonexistence of any contract between the union and the employer-a view possibly explained by the fact that under judicial conceptions of its status, the union is not in a position to offer any obligation in return for the benefits conceded by the employer. Practically, the agreement becomes effective only when each individual employee contracts with the employer to receive for his labor the terms of employment which it recites. Generally, this means that each employee must have the terms of the agreement in mind when he is hired and must stipulate that they are to control in his.case. It is really inaccurate to call the individual employment relationship a contract, since each worker is actually employed only at the will of his employer. Of course, an employee suing for back wages always brings suit on the theory of an implied contract to pay him the value of his services. If he cannot prove an agreement to pay so much per unit of time worked, the jury fixes a fair value.

If, however, the employee bringing suit has worked under a collective agreement, then according to the custom or usage theory he may look to that agreement for the terms covering his employment, as long as he can prove that he had such terms in mind when he was hired. Apparently it makes little difference under this theory that an employee claiming the benefits of a collective agreement does not belong to the union-at least if

sa Young v. Canadian Northern R. Co., [r93I] A.C. 83.

${ }^{2}$ Hudson v. Cincinnati R. Co., I52 Ky. 7 II, I54 S.W. 47 (I913). 
the agreement does not specify that its terms cover only members of the union. Such stipulations are rare, if they exist at all. But whether or not he is a member of the union, only the employee claiming rights under the agreement may enforce such rights by court action. The union has no rights under the contract which it may have enforced at law. It is free to help the individual prosecute his law suit. But it may procure enforcement only through the more primitive self-help method of striking.

A second category for the judicial enforcement of collective agreements-the agency theory-is no improvement on the custom or usage theory. According to this approach, a union acts as the agent of its members to bargain with the employers over the conditions of their labor. ${ }^{3}$ Courts accepting this theory unfortunately attempt to apply the conventional rules of law governing agency relationships in the business world. Hence they assert that the union, as such, is not the real contracting party, since it is only an agent. Here again, only individual employees with grievances may press claims under the agreement, their ultimate recourse being personal litigation in the courts. And since they theoretically bring suit as "principals" of the agent union, only members of the union may secure from the courts compliance with the terms of the agreement. Presumably members employed after the agreement has become effective may not acquire rights until they have ratified its provisions. And for that matter, in the absence of a clear-cut principle of majority rule such as we know it today under NLRA developments-either stated in the union's constitution and effected thereunder by a vote of the membership ratifying the bargained agreement or arbitrarily imposed by the courts-any member may disclaim a term of the agreement or repudiate a subsequent collectively bargained adjustment affecting his rights, unless his personal ratification was secured.

Little hope lies in the trend toward the third category for the judicial enforcement of collective agreements-that called the beneficiary theory. ${ }^{4}$ Under this development, copied directly from conventional contract law prevailing in some of our states, a union enters into a contract with an employer for the benefit of those workers whom the contracting parties intend to cover. Although the employees benefited are not parties to the contract at all, they may nevertheless secure judicial enforcement of its terms under this theory. Here the union is necessarily a party to the collective agreement, although many unions so recognized under this theory 3 See
(r93I).

${ }^{3}$ See Rice, Collective Labor Agreements in American Law, 44 Harv. L. Rev. 572, 594

${ }_{4}$ Ibid., at 596 et seq. 
have no separate legal personality except that lent them by the courts in order to make the theory work.

Under this theory an employee may secure judicial enforcement of the collective agreement in his own behalf even if he is not a member of the union, as long as he can show that it was the intention of the contracting parties to allow him the benefits of the contract. But this theory, like the others, is hopelessly involved with legalistic paraphernalia, bad enough in the contexts where it was originally conceived and utterly out of place in the field of labor relations. The third party beneficiary theory in the law of contracts-a far from universally accepted piece of judicial legislation, adapted to the intricacies of mortgages and suretyship-provokes the most ridiculous legalistic speculations when it is grafted on to the field of labor relations.

It is not profitable to discuss further any of these judicial theories. Some consideration of them was necessary to show the futility of adapting common-law principles, developed for another purpose, for use in the labor relations field. It is probably unfair to blame our courts for having done no better, since they are not supposed to cut new paths. Their function may include occasional stretching of legal principles to encompass new situations. But the social change has been too rapid and violent in ths field to allow for the slow process of judicial adaptation. Even if judges were inclined to cut through the conventional legalisms and achieve rules to govern the enforceability of collective agreements, they are not expert in labor matters and would probably disagree among themselves as to how they should be handled. Furthermore, they would not have the power to set up effective ancillary procedures like arbitration. These commonlaw theories which they developed are inadequate because they do not allow for suits by unions against employers nor for suits by employers against unions and individual employees under these agreements.

What we need immediately is a thoroughgoing legislative treatment specifically designed to make collective bargaining and the resulting agreements work smoothly and efficiently. And the less such legislation depends for its measures on the conventional law of contracts, the better it will be. Perhaps it would be wise for legislatures to assume in this task that collective agreements closely resemble treaties of peace, requiring sanctions to compel all parties concerned to observe their freely made commitments. They might, indeed, bear in mind Justice Jackson's observation, in his opinion in J. I. Case Company v. NLRB that the term "trade agreement" is more appropriate than "contract," as well as his ${ }^{5} 3^{21}$ U.S. $33^{2}$ (1944). 
suggested analogy between these agreements and certain types of fixed schedules of terms controlling individual contracts. In this recent case he likened these collective labor agreements, in their practical effect at least, "to the tariffs established by a carrier, to standard provisions prescribed by supervising authorities for insurance policies, or to utility schedules of rates and rules for service, which do not of themselves establish any relationships but which do govern the terms of the shipper or insurer or customer relationship whenever and with whomever it may be established." He also called attention to the fact that in some European countries a. privately negotiated trade agreement of this sort, when approved by an appropriate government agency, becomes a "governmental regulation ruling employment in the unit." Apparently he envisioned individual employment relationships-contracts of employment, if that is preferredcreated between employer and employee, automatically including the terms set forth in the controlling trade agreement.

Legislatures should note that Justice Jackson was suggesting only a rough analogy between collective agreements on the one hand and tariffs, standard provisions, and rate schedules on the other. Unlike these situations, collective agreements are bargained out between private personsunions and employers-who regard themselves as parties to these agreements, with rights and obligations apart from those of the individual employees. The final agreement is intended to reflect the mutual intentions of the parties, indicating that which each was able to secure from the other in a series of horse trading conferences which involved all sorts of concessions and compromises. The extent to which this might be true naturally depends on the relative bargaining strength of the parties-the willingness and ability of the union to strike and the ease with which the employer might resist such pressure. On the other hand, to pursue Justice Jackson's analogy, the terms of a collective agreement are usually applied to all employees in a unit.

However a legislature may go about setting up a procedure for the application and enforcement of collective labor agreements, it is faced with the fact that thousands of these agreements now exist in some sort of practical working order. Collective bargaining practices now in everyday use are far ahead of anything the courts and the legislatures have ever conceived or even pondered about. Hence, projected legislation will have to be planned in accordance with these developments, reflecting many of the techniques already adopted by employers and unions as well as some of those imposed by the National War Labor Board.

${ }^{6}$ Ibid., at 335 . 
For instance, in the garment and soft coal industries, the employers and unions concerned have long since worked out for themselves fairly adequate procedures to dispose of contentious issues arising under their collective agreements. In each, the collective agreements involved are either industry wide or cover large blocks of an industry in a particular locality, usually master agreements between associations of employers on the one hand and national unions of affiliated locals on the other. While the garment industry has tended to secure the interpretation and application of master contracts through the use of a privately retained impartial umpire, the soft coal industry depends on the decisions of regional joint boards composed of employers and union representatives, with ultimate recourse to arbitration, if necessary. But these are voluntary arrangements. Their success lies in the civilized determination of the contracting parties to make them work, as the only practical alternative to chaos. They amount to a type of self-government, without legal sanctions, existing within a political government which should provide adequate sanctions to insure the operation of such arrangements throughout industry in general.

The first thing to decide in any projected legislative program concerning collective bargaining agreements is whether or not the collective bargaining process should itself be regulated. This process, which results in collective agreements, must be considered in sharp contradistinction to the application and enforcement of such agreements after they are once achieved. Regulation of the collective bargaining process happens to be one of the most fundamental issues in the contemporary labor relations field. Traditionally in this country the private parties concerned have conducted the negotiation of collective bargaining agreements, government having intervened through mediation and conciliation merely to get the parties together on some mutually satisfactory compromise basis. The backbone of collective bargaining has always been economic coercion, which includes union recourses like strikes, boycotts, and picketing, as well as employer recourses like shutdowns, lockouts, and farming out work. Naturally, a good deal of collective bargaining takes place around a conference table, but those who believe that such parliamentary procedure is all there is to collective bargaining are just kidding themselves. Possibly the word "bargaining" is a misleading term for this whole process, and terms like "hold up" or "starve out" may be more accurate. But such speculation seems beside the point at this late date.

A question of primary political importance is whether or not employers and unions are willing to abandon their traditional techniques of bargain- 
ing in exchange for the terms of employment which some appropriate government agency might believe suitable. And if they are not willing to abandon these traditional techniques, should they be made to do so in the general public interest? Although these speculations might not have been taken seriously before the war, they must now be carefully considered in view of the remarkable performance of the War Labor Board. That board's function was to do the collective bargaining for employers and unions who could not manage to do their own. It undertook this task on the assumption that a nation at war could not afford the disruptions which the traditional collective bargaining process might occasion. Its success was due largely to the fact that employers and unions co-operated in accepting and following the policy pronouncements and decisions of the board. Many people have been so favorably impressed by this experience that they would like to see something of the sort set up as a permanent institution. But there are a number of angles they may have overlooked.

In response to the first question above, it seems unlikely that many employers or unions would wish to abandon the traditional techniques of collective bargaining. Most employers would probably like to see the economic bargaining devices of unions completely abolished by law, but they know that this is politically impossible. Indeed, most of them would regard as highly undesirable the only form of government which would make suppression of that kind possible. Quite obviously, the unions do not want to give up their traditional bargaining techniques like the strike. Some employers and a few union leaders might be willing to take a chance on government-imposed collective agreements, but only on the gamble that a particular political administration would lean more toward their side than the other. This possibility of politically influenced bias, however, is probably what makes most employers and labor leaders nervous about government-conducted bargaining. They would vastly prefer to take their chances on private bargaining, even with all the trouble that that choice inevitably entails.

As to the second question, in the absence of a paramount national emergency it is almost impossible to justify governmental assumption of the collective bargaining function, even for the purpose of obviating the wasteful and disruptive strikes and boycotts associated with private bargaining. This is so, chiefly because there are no known standards by which government supervised collective bargaining can be conducted. Naturally, standards of some sort could be adopted by Congress. That is what everybody is afraid of. If it goes that far, Congress might just as well fix prices and wages and be done with it. We could, of course, have our economists draft standards to govern collective bargaining. 
Then the questions would arise: Which economists? And, who would select them? Would they be those reflecting employers' beliefs, those reflecting the sentiments of organized labor, or those reflecting one of the intermediate philosophies? Would the test of competing economic theories be their relative worth, if there be anyone to make the choice, or would it be a show of hands on the floors of Congress? In a country whose only labor policy so far is to have no labor policy, these would be difficult questions to answer. Indeed, any answer would imply a kind of regulation completely at war with the prevailing notions of free enterprise so deeply entrenched in the minds of both employers and organized employees. Each group would like regulation of the other, even if that meant some invasion of free enterprise; but, in the last analysis, they would all agree that complete free enterprise for every economic undertaking is better than none for anybody.

Naturally, a middle course suggests itself. And it is no idle speculation to foresee the possibility of something like the "codes of fair competition" current in the NRA days of I933. This time, however, the main object would be to fix uniform labor standards throughout the various industries, with allowances for local and regional variations warranting occasional differentials. And organized labor would enjoy parity with the employers in establishing these industry-wide codes. Inevitably, an undertaking of this kind would require price-fixing of commodities, and the distinction between such a setup and a planned, noncompetitive economy by direct legislation would be hard to discern. One obvious distinction might win the approval of some employers and labor leaders. In a scheme of this sort the bargaining function would still be present, making it possible for employer and employee groups to negotiate compromises. The final result would be called a collective agreement. The only possible catch might be that the government would resolve all failures to reach decisions, a factor which might easily keep one side or the other from committing itself, depending on the known political temper of the administration in power. And since such arrangements would necessarily have to cover entire industries, the expectation of securing a united labor front through unions now competing in the same field seems hopeless.

ISSUES ARISING UNDER COLLECTIVE AGREEMENTS-GRIEVANCES

AND THE INTERESTS OF NONMEMBERS

Although it may be incorrect to assume that projected legislation will not include government regulation of the collective bargaining process, this assumption is necessary for a profitable inquiry into the application and enforcement of collective agreements. Any legislation concerning this 
intensely practical matter must be carefully adapted to practices already established either by custom between employers and unions or in accordance with the law. For instance, it will have to provide that all members of a given bargaining unit are covered by any collective agreement negotiated, since the NLRA already stipulates that the bargaining agency selected by a majority of the employees in a unit is the exclusive bargaining representative for all of them. And new legislation of this type should reflect all implications of the majority rule idea if it is to be completely consistent with the policies of the NLRA. Practically, this means giving unions a separate legal identity for all general purposes-to contract, to sue and be sued-possibly subject to their having registered with some state or federal agency in accordance with certain stipulated formalities. Or it could mean establishment of a series of specified detailed union privileges covering the same ground, not subject to modification through judicial interpretation but less flexible in their application than more generally described powers. Incidental to this, unions must be allowed to bind all employees in the units they represent, whether such employees be members or nonmembers, to any commitments they may negotiate with the employers concerned.

Many may think this last provision an extraordinary power to grant a union over employees' vested interests, such as accumulated seniority rights of great value to them. But unless unions have this power, assuming that they must use it impartially for the benefit of the employees as a whole, they will not be able to operate for the best interests of all concerned. A possibly unusual illustration-a situation which has nevertheless actually occurred in the railroad industry-indicates why this is so. Suppose two companies of equal size, producing the same kind of goods and having adjacent plants, decide to merge into one company, whether for purposes of efficiency and general economy or for other reasons. A part of this merger may be a consolidation of similar departments in order to avoid duplications of machinery, transportation, and supervision. Also assume that each company had been under separate but practically identical collective agreements with the same union. Omitting any consideration of how necessary reductions of the working force might be effected, how would the seniority list in a given department of the new company be drawn, assuming that the personnel in the formerly separate departments were placed together in the new consolidated department?

Presumably, the union could cancel the old contracts and negotiate another with the new single employer. If it did this, could it negotiate a new seniority list for the department in question, dovetailing the two old 
lists so that the service of each employee in the new department is properly reflected in his relative position on this list? Many of the individual employees would no doubt complain, if this were done, that they have lost their positions of relative advantage on the seniority list. Thus, one who had been tenth on the old list in his former job, now may be eighteenth on the new list. Actually, he would have gained by the change, assuming that the new department is just twice as large as either of the old ones, although this factor should be immaterial if his relative length of service is accurately stated. At any rate, if the union were not allowed this power to negotiate reasonable adjustments over the objections of the employees concerned, adequate collective bargaining in this instance would become impossible.

It might be thought necessary in a case like this to allow the individual employees an opportunity to secure a judicial declaration of what should have been done and whether their relative seniority positions should have been maintained, but this would seem most unfortunate. Naturally, these employees should have the opportunity to prevent an arbitrary disposition to their rights, just as minority stockholders of a corporation may complain of the unwarranted excesses approved by the majority. But that is far different from substituting a court's notions of proper collective bargaining for those authorized by legislation. In such a situation, the court should be confined to reviewing the union's exercise of authority, remaining free to declare the particular negotiation an excess of power only if it found that the union and the companies had exceeded the scope of bargaining authority set forth in the statute. And similar treatment would be appropriate for other kinds of negotiations between a union and an employer, such as agreeing to a wage cut in the face of adverse economic conditions otherwise endangering continuation of operations. For it would seem that a far-reaching application of the majority rule principle is imperative to successful collective bargaining, even if it means vesting all bargaining power and representation in the unions, leaving the employment interests of individual workers completely in their hands. If any of the employees dislike the representation that a majority of their fellows have selected, they are always free to campaign for another union or for no union at all, or to find work elsewhere.

Acceptance of these conclusions should not imply a denial of opportunities for individual employees in bargaining units to secure redress for violations of their established rights under collective agreements. Certainly such opportunities should be available to all individual employees, but great care is necessary to determine what these rights are, how they arise, 
and a practical procedure for their adequate enforcement. Any claims asserted by individual employees working under a collective labor agreement will presumably be made against their employer. Among such claims would naturally be included demands for wages earned but either not paid at all or not paid in proper conformance to the established rate, to the number of hours worked, both straight time and overtime, or to the scheduled job classifications. Inasmuch as claims of this type are more or less routine-frequently arising from bookkeeping errors in the employer's office, in time reports submitted to the office, and in particular employees' own faulty memoranda of time worked or misconception of their rights with respect to accurately kept personal memoranda-little harm and much good accompanies their direct submission to management by the individual employees. They are usually straightened out on the spot, to the mutual satisfaction of everyone concerned. In a way, such claims do not really involve the employees' rights under the collective agreement. They more closely concern his rights created in his personal "contract" of employment, since they do not reflect a misinterpretation of the collective rights so much as they indicate, rather, a misapplication of conceded rights to individual situations through erroneous conceptions of facts.

Now this is a broad statement. But it is intended only to suggest a valid distinction between claims made under clearly understood contract rights with respect to which a misconception of the actual facts exists, on the one hand, and claims made, on the other, under ambiguous or disputed contract rights with respect to which the facts are conceded. It is obvious that the clear categorical distinction between these two situations may easily become lost in particular cases, and occasionally it may seem to be only one of degree. The distinction is suggested only to show that there are certain types of cases easily and adequately cleared up by individual complaints made directly to management. As long as everyone concedes that such adjustments are not in themselves "bargaining," it is hard to see how their occurrence detracts from the function of the union as exclusive bargaining agency. Obviously, if such claims are not promptly and easily settled to the mutual satisfaction of the parties immediately concerned, they become grievances under the collective agreement as a matter of course. And while the union might appropriately have handled them in the first instance, at this stage its intervention becomes imperative.

These conclusions, regarding the power of a union acting as exclusive bargaining representative to dispose of all the details of employment which affect individual employees in a particular unit, have been sub- 
jected to serious question in a recent decision of the Supreme CourtElgin J. \& E. R. Co. v. Burley ${ }^{7}$-handed down in June, I945. This case arose under the Railway Labor Act and thus may not drastically affect the administration of collective agreements and union bargaining power in industry in general, because of the peculiar conditions prevailing in the railway labor scene. Nevertheless, it is a most disturbing invasion of the principle of majority rule and may have repercussions endangering the salutary developments of recent years in this direction.

In this case it appeared that certain individuals employed by the Standard Oil Company had operated railroad equipment in that company's yard in Whiting, Indiana. During I 934 the railroad took over these yards and the operators in question became employees of the railroad, as well as members of the appropriate brotherhood with which the railroad had a collective agreement. Four years elapsed thereafter before the railroad finally conceded that these employees should be governed by a certain provision of this agreement dealing with starting time. In the meantime, these individuals, through the union, had filed claims for penalty back pay with the Railway Adjustment Board, contending that the railroad owed them these accrued sums totaling around $\$ 65,000$, under the terms of the agreement. In I938 the railroad offered a settlement of these claims to the union, on the understanding that its acceptance would wipe out the claims for good. The officials of the union agreed to this settlement and the claims were formally withdrawn from the Adjustment Board.

Thereafter the individual employees concerned filed new claims for the penalty back pay incurred because of the railroad's noncompliance with the agreement. Naturally, the railroad pleaded the settlement of these claims with the union as a defense to their renewal. The Adjustment Board thought this defense good, so the individuals brought suit in the federal courts. Eventually five members of the Supreme Court held that the settlement by the union was no bar to their suit, while the four dissenting justices thought it should be a bar. Justice Rutledge, speaking for the majority, said that since the individuals had not expressly authorized this settlement, the Court must conclude that the union had no power in itself to settle already established claims for past money due over the heads of individual members of the unit, even conceding that it had the sole and exclusive power to bargain out conditions of employment to operate prospectively.

Justice Frankfurter, speaking for the minority, declared that this was not a simple case of a principal (the individual employees) attacking the

${ }^{7} 325$ U.S. 7II (1945). 
unauthorized act of an agent (the union). He insisted that developments in American unionism have been consistently in the direction of exclusive bargaining power in the unions representing employees. Also he pointed out that employees in the past have been dealt with severely for bargaining directly with individual workers who were represented by unions. He deprecated the distinction between bargaining over future terms of employment and the settlement of past due claims in favor of individuals. Thus he intimated that this decision is a severe setback to the principle of majority rule in American unionism and that, as a consequence of it, employers will be forced to abandon direct dealings with unions and to seek recourse to litigation as the only safe method of procedure in handling union affairs. The Court later consented to a reconsideration of this decision. But in March, I946, a majority of its members reaffirmed its original position in this case, ${ }^{8}$ in spite of the fact that the United States government, several of the railroad unions, the A. F. of $L$. and the $\mathrm{CIO}$, in general, joined with the railroad company in urging a reversal. The uncertainty resulting from the Court's qualified adherence to its original position in this case has apparently disrupted settled practices under the Railway Labor Act sufficiently to require Congress immediately. to pass legislation neutralizing the effect of the Burley decision.

Any supposed denial of rights under a collective agreement to individual employees or to whole groups of employees-constituting either a part of the bargaining unit or the entire unit itself-gives rise to a grievance or a series of grievances. Such grievances must be clearly distinguished from individual or group demands for additional rights, frequently wage increases, not already established in the existing agreement. The latter type of demand is not, strictly speaking, a grievance at all. It is, rather, a new collective bargaining demand and, while there is no harm in its being made during the life of an agreement, such a demand does not arise under the terms of the agreement. Indeed, its pursuit by selfhelp bargaining techniques such as the strike may be in direct violation of already established contract provisions.

Now, the prosecution of a true grievance arising under a collective agreement-either on behalf of an individual employee, of a group of employees, or of the entire unit-may accurately be described as a type of bargaining in itself. That is to say, it is bargaining expressly contemplated in the grievance procedure. Such a process is different from collective bargaining-which term is used to denote the negotiations leading up to the collective agreement itself. Nevertheless, the process of handling a grievance

${ }^{8}$ Elgin, J. \& E. R. Co. v. Burley, 66 Sup. Ct. 72I (I946). 
is a kind of bargaining, since it normally looks toward a settlement either by the employer's eventual acknowledgment of its justice, by some compromise, or by some further step such as arbitration when the employer stands pat and the union refuses to admit that it is wrong.

One may well ask by what right a union shall intervene between the employer and the individual employees or groups of employees in order to represent the latter in handling their grievances. Why should an individual employee not be free to settle on any grounds agreeable to him, or to dismiss entirely any grievance he has raised concerning his personal interests? And why should an employer not be free to deal in this way with the individual employee? Why is not a union's collective and representative function fulfilled when it has bargained out an agreement? There may be many answers to these questions. One of them certainly is that this adtional representative function is customarily undertaken by unions, quite often in conformance to express provisions in the grievance procedures outlined in collective agreements. And it is much better that way for practical reasons. Most individual workmen are not able to deal with such matters. They may be skilled craftsmen or they may be common laborers, but whatever they are, they frequently lack the interpretative and forensic abilities to deal with business matters of this sort.

Then again, the whole point of collective representation in the first place was to avoid direct dealings between an employee and his employer because of the inequality in their relative bargaining power. This point might be lost if the employer were permitted to deal with individual enployees directly for the purpose of settling grievances which arose under an agreement bargained collectively between him and the union. Furthermore, the union itself, on behalf of all the employees in the unit, has a very real interest in seeing that the terms of the agreement are observed in their practical, day-to-day application. Hence, it can hardly be expected to risk dubious precedents resulting from individual bargaining or to stand by and see what it fought for in the agreement being whittled away by the employer's settlements with relatively helpless individuals.

A very real problem occurs when nonmembers of the union raise grievances under the contract. Although it would be a stupid business practice, some people might suspect that a union would not prosecute such grievances faithfully, concluding that nonmembers should, therefore, be encouraged to settle their complaints with management. And this feeling of suspicion may be heightened where it appears that a favorable settlement of a nonmember's grievance would in some way be disadvantageous to a member of the union. Such a situation might easily arise over conflicting 
seniority claims between a member and a nonmember. Again, the answers to this problem may be manifold, but a few adequate answers seem apparent.

An established union in an open shop is anxious to convince nonmembers of its value to them in order to secure their membership. One of the best ways it can do this is by faithfully servicing their grievances. Such an undertaking may be difficult, when success means depriving a union member of some benefit he enjoys through the employer's misapplication of the contract. Any union representative is likely to hesitate before going to bat under such circumstances. Fortunately, however, such cases seldom arise, since the average employer may be trusted not to make many mistaken applications of the contract in favor of union, as against nonunion, employees. But even if he does, it seems fairer in the interests of expediency to allow the union the sole right of handling grievances with the employer, in view of the harm to collective representation which may ensue from any other course. After all, a nonunion employee in such a plight belongs to a group in which the majority has selected the union as their exclusive bargaining representative. Under the principle of majority rule, it seems fair enough to make him accept the imperfections of that system along with its benefits, one of which is the very provision which has given him the right to raise a grievance in the first place. Furthermore, he is free to join the union any time he concludes that his nonmembership is disadvantageous to his interests.

Many unions, certified as exclusive bargaining representatives of all employees in open shops, bitterly resent the ability of nonmembers to enjoy all the benefits of collective bargaining without contributing in any way to the support of the unions who secured these advantages. These nonunion members of the bargaining units accept seniority, vacations, and wage increases, expecting to have all of these advantages secured to them in strict accordance with the terms of the agreements. Yet they did not contribute to the expense of the original bargaining negotiations and paid nothing toward the upkeep of these contracts. As the union men see it, these free riders make nonunionism pay dividends, for they earn just as much as the union members and are able to keep in their pockets what their organized fellow-workers pay out in dues. Of course, the unions realize that if collective bargaining is going to be effective, it must introduce uniform standards throughout a unit, for union and nonunion employees alike.

When a union is unable to secure a closed shop contract in a unit, its members know that the price they must then pay for the advantage of 
exclusive bargaining rights in that unit is the overhead cost of this privilege. Unions nevertheless prefer it that way to allowing a cleavage between higher union and lower nonunion standards of employment in the same unit. While this divergence of standards might induce nonunion employees to join the organization, past experience indicates that it might eventually insure the undermining of union standards and, possibly, of the union itself. For the introduction of lower nonunion standards might give the employer an incentive to hire only people willing to work under such standards. Unions have bitterly fought this sort of thing for decades. They found in the past that the closed union shop was the only protection against it. For if all employees belonged to the union, they worked under union standards and the employer could not introduce lower standards to compete with them.

Under the NLRA, however, unions know that their standards cannot be undermined in this way, even in an open shop, now that their collective agreements introduce uniform standards. This is something for which they are thankful. But they and their dues-paying constituents now fail to see why the nonunion employees should not share the cost of achieving these benefits. The way to make them share, of course, is to get the closed union shop and establish union membership in good standing as a condition of continued employment. During the next few years, this element of union discontent is bound to intensify the drive for closed union shop contracts. The inevitable clash might conceivably be settled without conceding the closed shop by checking off from nonunion employees' pay amounts equivalent to union dues and assessments and paying this money over to the unions.9 Perhaps a less shocking compromise would be for each employer to pay this checked-off money to some charity.

Either way would deprive the nonunion employees of their advantage over union workers and would serve to keep labor standards uniform. But only the former method would keep the unions from pressing for the closed shop and, under the present state of our law, both methods might easily render the employers liable to their nonunion employees for the amounts checked off. Hence, we may expect determined union drives for the closed shop or for legislation permitting employers to check off the equivalent of union dues and assessments from the wages of nonunion employees, to be paid to the bargaining representatives acting for them. And if the unions base this legislative demand on the legal theory of an implied contractual right to compensation for services rendered and a

\footnotetext{
- See decision of Justice I. C. Rand in the arbitration proceedings between the Ford Motor Company of Canada and the UAW-CIO. I7 L.R.R. 813 (r946).
} 
corresponding obligation for services accepted, society cannot afford to laugh this off. They will be deadly serious about it.

In the meantime there will remain the practical difficulties apparent when a union is obliged to prosecute grievances filed under a collective agreement by nonunion employees. But the foregoing discussion may indicate reasons why we should not feel too sorry for these employees. If collective bargaining and collective representation are to become the future basis for industrial democratization, in which the majority rule is to prevail, then society should no more pity these nonunion employees than it does a citizen denied social benefits because he refuses to pay his taxes. People who think unionism is bad for our economy will naturally disagree with this because it would tend to force all nonunion employees into the unions representing them. But in light of what has been happening in the development of labor policy affecting unions, they must concede that a trend of this sort is politically foreseeable.

\section{ARBITRATION-ITS SCOPE AND POSSTBLE IEGISLATIVE BACKGROUND}

The state courts afford individual employees no practicable recourse in the pursuit of their rights under collective agreements. Rather than go to the extreme of suing in the courts, most of them would prefer to pocket their losses and wait until justice is less expensively and more conveniently achieved. Yet this is all that our law at present provides. Even this recourse is uncertain and enshrouded with conflicting legalistic theories. And if a union were willing to bring suit on grievances arising under collective agreements, either on behalf of individual employees or for a whole bargaining unit, it is doubtful under existing judicial authority whether it might do so. There are isolated instances of unions securing judicial aid in compelling employers to comply with collective agreements. But there is little reason to believe either that such precedents will be generally followed or that they point the way to a proper solution of this vexing problem.

The fact remains that the courts do not provide either an adequate or appropriate method of applying and enforcing collective agreements. Employers and unions are aware of this. Just as the merchants in the medieval fairs set up their own informal "courts" to adjust their mutual differences on the spot, so a few employers and unions have established their own procedures for settling disputes arising under collective agreements. The "law merchant" was eventually absorbed into our common law after some centuries had elapsed. In time our common law might adapt itself to the practical needs of labor relations and reflect some of the techniques developed by these employers and unions. But society cannot wait for this to 
happen, even if it wanted the courts to assume control of applying and enforcing collective agreements. Only the legislatures are able to intiate these settlement procedures for general application throughout industry. And if they are to be uniform, Congress is the only legislature up to the job.

Arbitration affords an expeditious and inexpensive procedure for the settlement of labor grievances. Yet most employers and most union leaders are suspicious about arbitration-at least, until they have tried it. The nature and scope of this process must be carefully defined before their suspicions are allayed. Now, arbitration is an informal procedure for deciding disputed issues. While it can be used as a substitute for collective bargaining, in order to break a deadlock in negotiations between employers and unions over the terms of a collective agreement still in the making, its use for this purpose hardly seems to be real arbitration at all. This is the sort of thing the War Labor Board did as a substitute for collective bargaining over the terms of agreements during the war. But nobody thought of the War Labor Board as arbitrating disputes!

Indeed, it is practically impossible to arbitrate deadlocks of this type in the absence of generally conceded standards of decision. Real arbitration would properly seem to imply the disposition of a dispute in accordance with some standard-possibly a law, a trade practice, or a provision in a contract-which the parties to the dispute concede to exist, although they cannot agree upon what it means or how it is to be applied in the particular case. Collective bargaining over the terms of a collective agreement, on the other hand, is not a process involving the application of a standard of any sort to a specific situation. Collective bargaining is, rather, an attempt to establish standards-the standards of employment which are in themselves the subject of dispute.

The only conceivable standards that might govern collective bargaining negotiations are general economic standards, and the consensus around the table on these may be easily imagined! To be sure, arbitrators could establish standards if they had to do so. But it seems absurd to let them draw upon their personal notions of economic values in order to break collective bargaining deadlocks. Indeed, this could hardly be termed the application of external standards, no matter how objective the arbitrators might be. Congress, presumably, could legislate standards through the exercise of its political process. But if it went this far, it would probably not leave their application to private arbitrators. More likely, it would set up an administrative commission under which so-called "arbitrators" would decide particular cases in accordance with these standards, their 
"awards" being subject to the commission's approval. At any rate, employers and labor leaders might well remain suspicious about arbitration in view of the current loose usage of that term in connection with resolving collective bargaining disputes. Rather than entrust their affairs to such an ill-defined procedure, they would understandably prefer to fight for what they can get by recourse to traditional collective bargaining techniques. And dressing up this process in the cloak of "fact-finding" provides a poorly disguised substitute, hardly adequate to allay these suspicions.

In a labor relations context, arbitration more accurately implies the interpretation and application of an already achieved collective agreement in the disposition of specific grievances raised under that agreement. There the arbitrator is at liberty to act only within an area that the parties to the agreement had ample opportunity to define in considerable detail. Of course, employers and unions cannot possibly anticipate all possible exigencies and provide for them in their agreements, and what they do cover in advance is frequently couched in ambiguous language. Amazingly different and conflicting interpretations can be read by opposing counsel into apparently clear sentences or phrases used in the agreement to express the mutual intentions of the parties. Sometimes whole sections appear to have been written with such ambiguity that they suggest the studied effort of the parties to remain unclear, each in the possible hope that a decisive meaning will ultimately be supplied in his favor. But the arbitrator has to give meaning to the provisions of the agreement as he finds them, after the parties have had a chance to argue their respective interpretations before him. At least he has something fairly definite to apply to specific fact situations brought before him. And when the terms of the agreement are not as definite as they might be, the parties have only themselves to blame if they do not like the construction which the arbitrator puts on them.

But even this limited scope of arbitration seems too broad for many employers and labor leaders. They still fear the discretion which an arbitrator may exercise over their affairs in accordance with his personal opinions and economic predilections. Nevertheless, a few employers and unions have for some years voluntarily submitted their grievances to arbitration. And during the war many of them have become accustomed to arbitration, after it was included in their agreements by the War Labor Board. As a result, it seems likely that some sort of limited voluntary. arbitration will generally prevail in the future as the final step in the prescribed grievance procedures of most collective agreements.

In a system of uniform arbitration lies the only real hope for the smooth 
operation of an industrial society governed by the terms of collective agreements. The foregoing discussion certainly indicates the impracticability of direct recourse to the courts for the settlement of disputes arising from these agreements. Such a recourse is expensive and time-consuming at best. In any event, our courts are not geared to handle matters of this nature. Only our legislatures can create the necessary procedures and sanctions behind a successful system of arbitration. If this system is to be uniform, then Congress should assume exclusive jurisdiction and promulgate a consistent procedure, including provisions for the enforcement of awards. That uniformity is essential seems obvious, in view of the presentday organization of industry in far-flung corporate units covering vast areas of the nation. A union and an employer operating under a master agreement covering plants in several states could hardly be expected to conform to as many different procedures in the application of that contract-a likely consequence if projected legislation is left to the various state legislatures.

But a vast program of this kind must be approached with great care, for several aspects of it are bound to make unions and employers very nervous, indeed. Most of this feeling of distrust arises from the fear that arbitration will become compulsory. Too many people immediately jump to the conclusion that this process necessarily means the compulsory settlement of all labor disputes-even those involved in collective bargaining-and they shudder at the idea of having to live under agreements ultimately written by arbitrators. These fears will hardly be justified if employers and unions are assured that compulsory arbitration will be confined to the interpretation and application of privately negotiated collective agreements, especially if it appears that they will be left free to choose their own arbitrators.

Legislation introducing arbitration should simply require it as the final step in the grievance procedure of every collective agreement, available for the resolution of all differences between employers and unions which arise under their mutually negotiated collective agreements. Employers and unions already know that there has to be some convenient and expeditious method for clearing up not only the routine grievances but also the more fundamental issues so frequently arising under collective agreements. They know that these agreements as a rule exist only from year to year, and that it might take twice the life of any such agreement to secure an interpretation and application in a court, if a decision on the merits could be secured at all. As long as they are assured that the scope of compulsory arbitration is defined as suggested, they will accept it with a good grace. 
For any opposition to such limited arbitration would imply that they do not wish to observe their collective agreements but would prefer recourse to primitive trial by combat - a procedure which society may grudgingly tolerate while an agreement is in the making but which it can no longer afford to condone after an agreement is reached.

If employers and unions are first assured that compulsory arbitration will be thus limited in scope, they can then divert their energies to seeing that the proposed statute contains adequate provisions. For instance, they could suggest that arbitration awards should be enforceable only by court orders after a judicial review of the awards. They might publicly explore the purpose and extent of such judicial review-whether it would be on the merits of the arbitrator's award, on the arbitrability of the issue decided, or on the authority of the arbitrator to act as he did under the proposed statute, regardless of how he decided the issue on its merits. For the employers and unions concerned might wish some protection against an arbitrator's assumption of power to pass on matters properly the subjects for collective bargaining or to exercise authority in a manner not consistent with the stipulated procedures. Conceivably, they might try to exclude from arbitration any issue that depends for its disposition on the application of some state or federal law or administrative decision covering the subject matter in issue. And they might debate sanctions against the failure of either employers or unions faithfully to abide by their undertakings in collective agreements to settle all their differences under their mutually accepted grievance procedures, including arbitration.

It would be unfortunate if some of these provisions were actually adopted. Of course, the judicial enforcement of arbitrators' awards is essential, for if the losing party can successfully defy an award, the whole procedure would be jeopardized. On the other hand, it is natural to expect that Congress would not make awards automatically enforceable by court decree without some sort of judicial review. But the whole purpose of arbitration would be defeated if the losing party were permitted to retry his case before a court. If this procedure is to work at all, it must depend on faith in the arbitrator's judgment.

Even if a court should disagree with an arbitrator's award in a particular case, either on his statement of the facts and the issue, his interpretation of the evidence offered, or his construction and application of the contract, that does not mean that the court is right and the arbitrator is wrong. The award should still be enforced if the court finds that the arbitrator has not abused his authority as defined in the proposed statute. And the award should stand even if the court believes that the arbitrator has made a decision on an issue which it believes not to have been arbi- 
trable at all under the agreement. After all, an arbitrator should be quite capable of deciding that matter himself. If he is honest and sufficiently clearheaded, he will recognize the nature of such an issue and will not hesitate to deny a decision on its merits. Under the projected statute a court should deny enforcement of an award only if it finds that the arbitrator has clearly abused his power in a capricious and prejudicial fashion or has not faithfully adhered to the procedures stipulated by Congress.

A statutory provision denying an arbitrator the power to decide issues which depend for their settlement on the interpretation and application of state or federal laws or administrative rulings would be most distressing. It is true, some people believe that it is bad practice for an arbitrator to accept jurisdiction over such issues. But if, as frequently happens, the parties voluntarily submit to arbitration an issue requiring the interpretation of some law, it is hard to see what harm can accompany this practice. Under compulsory arbitration it might be reasonable to make such awards unenforceable unless the reviewing court agrees with the arbitrator's view of the law in question. But this is not really necessary in most cases, because the arbitrator cannot by his award foreclose official consideration of such situations.

For instance, if he has before him a grievance based on the alleged discriminatory discharge of an employee and he decides that the discharge was not discriminatory but was for proper cause, nothing he has done can foreclose the NLRB from thereafter concluding otherwise. Similarly, if an arbitrator gave an award to a union on the basis of the Wage and Hour Act, involving rates and back pay of employees who are really under the jurisdiction of the Interstate Commerce Commission and excepted by a ruling of that commission from the terms of the Wage and Hour Act, the employer could secure an official disposition of this case in his favor. The fact remains, however, that many employers and unions prefer to submit these issues to arbitration in order to expedite their settlement. In 99 cases out of 100 they would accept the award, whether or not they agreed with it.

A section in an arbitration statute providing penalties against failures of the parties to abide by those terms of a collective agreement outlining the settlement of disputes which arise under the contract would have to be carefully drawn. Incidentally, this suggests one of the practical problems involved in the enforcement of labor agreements-the fact that it is much easier to compel compliance by an employer than it is to compel compliance by a union. If an employer fails to observe some provision of benefit to an employee or to the union, he can be compelled to make amends by back pay or some other tangible adjustment. But if a union or a group of 
employees violates some term of the contract designed to secure advantage to the employer, it is almost impossible to impose a remedy or even to enforce future compliance, except by negative actions such as discharges and disciplinary layoffs. This may be due to the nature of a collective agreement, since it is a document in which are scheduled the terms of employment given by the employer to his workers. In short, the employer is conceding something and the employees are receiving something. What they give in return is, primarily, their labor. Hence, about the only kind of undertaking they can enter into collectively concerns their supplying of services.

Off hand, this suggests the no-strike pledge for the duration of the contract. Such a pledge may, of course, have reference to collective bargaining strikes in pursuit of advantages not already granted in the agreement, or it may have reference only to strikes called to secure a favorable settlement of some grievance or issue arising under the terms of the agreement, for the disposition of which a procedure is set forth in the agreement itself. About the only practicable measures possible against bargaining strikes in violation of a collective agreement are injunctions and actions at law for money damages. Abrogation of the entire contract is frequently spoken of as a possible device to discourage bargaining strikes in violation of a no-strike pledge. But this would be a ridiculous penalty, since nothing would be gained by it except a good deal of grief. In any event, these sanctions could not be administered by an arbitrator, even if they were provided for in controlling legislation.

A union's promise not to strike in order to secure the settlement of grievances and other issues arising under an agreement, however, is an entirely different matter. An arbitrator can fairly easily administer and enforce an undertaking of this type. If a union has called a strike or slowdown in violation of such a promise, the arbitrator can uphold the company in whatever appropriate steps it took to discipline the employees involved, such as layoffs or discharges. Moreover, in subsequent proceedings before him, involving the issue which occasioned the work stoppage, the arbitrator may give the award to the company because of the union's breach of contract, regardless of what he may think of the grievance on its merits. Of course, the arbitrator would impose this penalty only when it was requested by the employer in such a case. Where, on the other hand, an employer "struck" by refusing to take a grievance to arbitration, the arbitrator could be authorized by statute to hear the grievance from the union in the absence of management and to render an award in the union's favor if he took its views on the merits of the case. This would certainly be 
a sufficient sanction against an employer, as long as the union was permitted in this way to raise the grievance and secure a decision.

This discussion may seem to indicate that the only suitable function of a labor arbitrator is to interpret and apply the terms of collective agreements. But there are other situations where arbitration has been and will continue to be exceedingly useful and appropriate. Suppose that a bargaining strike is settled by a truce which provides that the employer in question will adopt rates equal to those paid for similar work in another plant organized by the same union. Because of variations in figuring rates in the two plants, due to different base rates and incentive plans, the parties are unable to complete their negotiations and agree to submit the effect of their truce to an arbitrator. An issue of this sort is reasonably suited to arbitration, because it involves the interpretation of an interim agreement, although it is a definite part of the collective bargaining process leading up to a final agreement.

Another type of arbitrable situation is the old-fashioned type of jurisdictional dispute. Yet this has nothing to do with the terms of any agreement. To use the classical example, suppose a dispute arises between the carpenters and metal workers on a construction job, concerning which union shall have the work of hanging metal doors. The carpenters claim they have always hung doors, even if they were formerly made of wood, and the metal workers claim that they have always handled metal, whether it was in fixtures, window sashes, or anything else, admitting, however, that they have never before hung doors. Even though there are few standards to guide him in this sort of situation, an arbitrator could adequately dispose of a dispute like this on the basis of testimony and findings concerning the background and history of the two unions concerned, with particular reference to their craft functions. Legislative authority for arbitration of these jurisdictional disputes, with a provision enabling enforcement of awards by injunction, should obviate one of the most wasteful and inexcusable types of strikes.

Aside from situations like these, opportunities for arbitration are rare in the absence of established collective agreements. Of course, if employers and unions agree to submit any conceivable issue to "arbitration," using that name to describe the method they choose for breaking a deadlock, they can no doubt get a settlement. After all, an arbitrator can undertake to pass on a requested wage increase with reference to the rise in the cost of living and to alleged reasonable standards of living, if the parties ask him to do it. Perhaps under such circumstances it is not even a misnomer to call this process "arbitration." But it seems wise to keep in mind that this method of settling such an issue is not arbitration as it has become 
known through practice in recent years. In any event; it would be a mistake to compel by statute the submission of such cases to so-called arbitration. If the government wants to provide an agency to settle issues of this kind without recourse to strikes, that is another matter. But the process would then more accurately be called compulsory "collective bargaining."

This brief account of arbitration can be justified only to suggest a practical device for interpreting and applying collective agreements. Individuals and groups of employees, or even unions representing them, cannot be expected to take their cases to courts, particularly under the present primitive stage of the common law concerning the enforcement of collective agreements. If a procedure is to be developed by legislation, it should be an adequate one, practically suited to handle specific requirements. Since there is great need for uniformity of procedure - particularly in view of the sectional and nation-wide character of so many corporate employers and affiliated unions-federal legislation equivalent in jurisdictional scope to the NLRA seems imperative.

Such legislation must carefully define the character of issues to be covered by compulsory arbitration. While it should no doubt state certain standard requirements as the basis of this procedure, it must leave employers and unions somewhat free to develop arbitration procedures of their own by mutual consent. It would be rash to suggest that state legislatures should not enact labor arbitration statutes, just as several have adopted state labor relations acts to perform locally the same function carried out nationally under the NLRA. But, in the interests of uniformity, Congress might well provide for federal judicial review of state court judgments enforcing or refusing to enforce arbitration awards in industries over which it has jurisdiction.

These are speculative issues, and they may seem to raise considerations far off the beaten path of the law. But the labor relations situation in this country is becoming increasingly complicated. Actual employer-union relationships in collective agreements are being created too rapidly for our existing legal machinery to accommodate. While the procedural developments which have occurred during the war may not be to everybody's liking, some of them seem much too valuable to lose through Congressional inaction. Everyone directly interested in these matters must face the fact that collective bargaining and collective agreements are here to stay. Everyone should realize that to avoid industrial chaos, a practical and effective procedure must be devised to make collective agreements stable and operative. In any event, now is the time for everyone interested to speculate on these matters, for the mold of our future law of labor relations is about to be cast. 